\title{
Study of Overseas Trade and Economic Potentiality of Maritime Sector in India
}

\author{
Dr. Vinay Kant ${ }^{1}$, Mr.Surya Prakash Yadav $^{2}$ \\ ${ }^{1}$ Research Supervisor sunrise university Alwar (Raj.) \\ ${ }^{2}$ Research Scholar sunrise university Alwar (Raj.)
}

\begin{abstract}
The Port of Kandla is located on the Gulf of Kutch on the northwestern coast of India some 256 nautical miles southeast of the Port of Karachi in Pakistan and over 430 nautical miles north-northwest of the Port of Mumbai (Bombay). It is the largest port of India by volume of cargo handled. Kandla history kandla Port Trust, India's busiest major port in recent years, is gearing to add substantial cargo handling capacity with private sector participation. The west coast port handled 72.225 million tonnes of cargo in 2012-13, over 11 per cent more than 64.920 million tonnes handled in 2011-12.

Even as much of this growth has come from handling of crude oil imports, mainly for Essar Oil's Vadinar refinery in Gujarat, the port is also taking measures to boost non-POL cargo. Last fiscal, POL traffic accounted for 63 per cent of the total cargo handled at Kandla Port, as against 59 per cent in 2011-12.
\end{abstract}

\section{Significance Of Study Of Kandla Port}

\subsection{Research Problems}

Statement of the Problem: I have chosen this topic to study about economic pattern of Kandla \& Non Major Ports with socio economic conditions and port development in Saurashtra and Kutch region. The study is mainly focused on various types of ports that are developed in the said region. This study highlights the problems during the development of ports and on other side gives suitable suggestions to improve their performance.

\subsection{Objectives of Research}

$>$ To study the income and expenditure statement of Kandla Port.

$>$ To study how port facilitate foreign trade volume.

$>$ To study about the cargo traffic of major and non major ports.

$>$ To study the ports infrastructural development.

To find out the income and expenditure pattern of Kandla port.

To identify the benefits and problems of ports.

To study future prospects and SEZ development of port.

To give suggestions for the improvement of ports.

\subsection{Area of Research - Gujarat,Kandla}

Kandla port plays a major role in the country's international trade. Having notched up a string of success, it has emerged as a forerunner, and has carved a niche for itself, by its steady growth and economy of operations.

The Port of Kandla was declared a major port in 1955. The Kandla Port Trust was created by law in 1963 to manage the new port. The Port of Kandla Special Economic Zone (KASEZ) was the first special economic zone to be established in India and in Asia. Established in 1965, the Port of Kandla SEZ is the biggest multiple-product SEZ in the country.

Covering over 310 hectares, the special economic zone is just nine kilometers from the Port of Kandla. Today, the Port of Kandla is India's hub for exporting grains and importing oil. This self-sufficient port is one of the highestearning ports in the country. Major imports entering the Port of Kandla are petroleum, chemicals, and iron and steel machinery, but it also handles salt, textiles, and grain.

${ }^{1}$ Corresponding Author: pramodietdms@gmail.com 


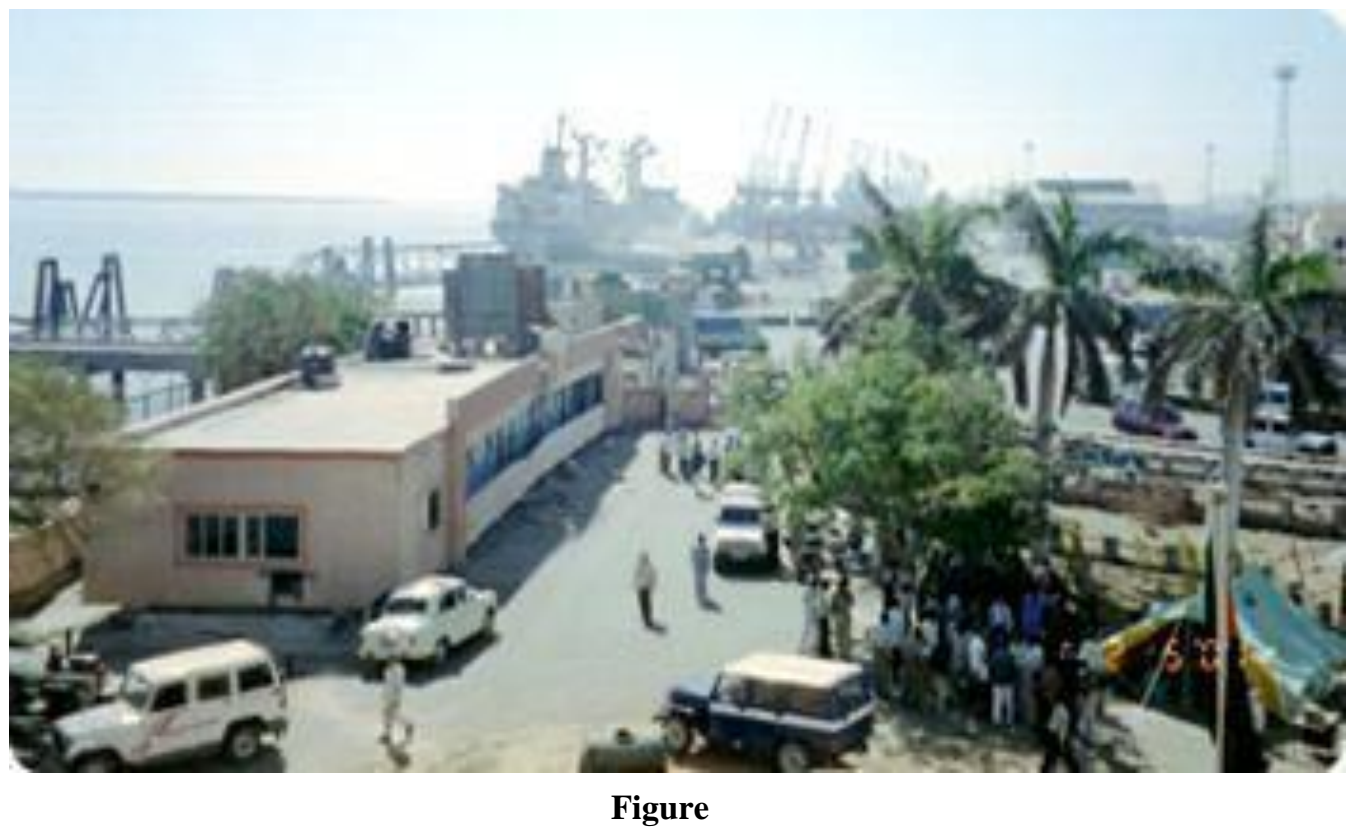

Kandla Port, a national port, is one of the eleven most important ports of India. This port is situated on Kandla stream. The first investigation of this stream was undertaken by the British Royal India Navy in 1851 and a detailed survey done in 1922. This port is developed by Joint project of Maharao Shree Khengarji-III and British Government in the 19th century.

The Kandla port came into existence in the year 1931 with a single Peir construction. Later on with the loss of Karchi port to Pakistan during partition, after independence the government of India chose Kandla as an ideal sea outlet. Thus the Kandla Port was developed and since then Kandla port has played a pivotal role in enhancing country`s maritime trade. Standard dry cargo treatment capacity of Kandla Port is 24,000 metric tons per day. The port is under Ministry of Commerce and is managed by a Port Trust with a Chairman as its head.

The Kandla Port Trust is run by a board of trustees. There is an administrator - representative of the ministry of Commerce - appointed for the management of a free trade zone known as the Kandla Free Trade Zone placed near the port where hundreds of small and international companies are also sited. Owing to fast progress of Kandla port close city like Gandhidham also developed faster. Kandla port plays a major role in the country`s international trade. Having notched up a string of success, it has emerged as a forerunner, and has carved a niche for itself, by its steady growth and economy of operations.

Kandla port is well equipped with infrastructural. It has 10 berths, 6 oil jetties, 1 maintenance jetty, 1 dry dock and small jetties for small vessels, which can accommodate from large to small vessels. Near all these terminals and jetties there are storage facilities for cargo from containers to petroleum. The port is also outfitted with Sixteen Wharf cranes. Apart from this, the port also provides for additional facilities for international traders. Due to its strategic location it is the connecting hub for Northern, Western and Central India.

Kandla also has the country`s only Free Trade Zone Kandla Port, the foundation stone for which was laid by Pandit Jawaharlal Nehru, has 1800 metres of dry cargo berths where in a straight line, ten ships could easily be accommodated. It has berths for a tanker also where chemicals, vegetable oil etc are handled. Kandla today has become the hub of India`s foodgrains and oil imports.

Kandla is a self sufficient, self enhancing Port. It is also among the highest revenue earning Port of India. The Port is the nearest, most economical and most convenient for handling imports and exports of the highly productive granary and industrial belt stretching across Jammu \& Kashmir, Punjab, Himachal Pardesh, Haryana, Rajasthan and Gujarat. Kandla Port is the most economical major port in terms of tariff and operational expenditure.

The efficiency and all requisite user facilities nevertheless confirm to international standards. The Port is up to date with the latest technological innovations.

The port has floated a global tender for a two-year capital dredging contract of 20 million cubic metre at an 
estimated cost of Rs 100 crore. Kandla Port attained new levels of performance in fiscal 2006-07, establishing a new record by handling a cargo volume of 52.98 million tonnes, in the process entering into the select league of ports that have registered a throughput of 50 million tonnes or more.

Excellent infrastructural facilities, well-connectivity with the rest of the country by road and rail networks, all-round services provided with efficiency and transparency, lowest port tariff and the envious cost-effectiveness are the major strengths of Kandla Port.

\section{LOCATION}

The Major Port of Kandla, situated about $90 \mathrm{~km}$ off the mouth of Gulf of Kachchh in the Kandla Creek at Latitude 23 degree 1 minute North and Longitude 70 degree 13 minutes East, is the lone Major Port on the Gujarat coast line along the West Coast of the country.

Amongst the 12 Major Ports in the country, Kandla occupies an enviable position, both in terms of international maritime trade tonnage handled and financial stability and self-sufficiency attained year after year. A gateway to the north-western part of India consisting of a vast hinterland of 1 million sq. $\mathrm{km}$ stretched throughout 9 states from Gujarat to Jammu \& Kashmir, the Port has a unique locational advantage. The Port's hinterland is well connected with infrastructural network of metre gauge and broad gauge railway system as well as State and National Highways.

\section{HISTORICAL LEGACY}

As a humble beginning in the year 1930 by the great visionary, the late Maharao Khengarji III of the princely State of Kachchh, for a deep-draught closed port in his kingdom, the Kandla Port on, with the loss of Karachi port to Pakistan during partition, independent India was deprived of a sea outlet in its North-West region. Major Port. Port of Kandla, since then, has been playing a pivotal role in the country's international maritime trade, contributing its mite for the growth and development of the national economy.

The Port has grown and matured itself not only in age but also in creating infrastructural facilities in and around the Port, handling volumes of import and export trade year after year and attaining a very sound financial status ahead of a number of other Major Ports in the country. Thus, Kandla Port has been playing a pivotal role in the national economy and contributing a handsome amount of foreign exchange earnings to the national Exchequer every year.

\section{THE EVOLUTION}

Due to the loss of Karachi Port to Pakistan after independence, the onus of entire Indian trade was shifted to the Mumbai Port putting tremendous strain on its facilities. Under the inspirational and able guidance of the great visionary and the Iron Man of India, Sardar Vallabhbhai Patel, the Indian government on 17th February, 1948 constituted an Expert Committee known as the West Coast Major Port Development Committee to explore the possibilities of establishing a deep-sea port to cater to the vast hinterland comprising the north-western states of the country. The Committee submitted its report on the 30th April, 1948, recommending that a Major Port should be sited at Kandla.

Accordingly, on January 20, 1952, Pandit Jawaharlal Nehru, the then Prime Minister of India, laid the foundation stone at Kandla for the new port on the western coast of India. It was declared as a Major Port on April 8, 1955 by Late Lal Bahadur Shastri, the then Union Minister for Transport. The Kandla Port Trust was constituted in 1964 under the Major Port Trusts Act, 1963. Since then, this Major Port of Kandla has come a long way in becoming the 'Port of the New Millennium'.

\subsection{Vision}

"To be Asia's Supreme Global Logistic Hub"

\subsection{Mission}

To transform the Port of Kandla into a most globally competitive logistics hub with international excellence leaving imprints in the international maritime arena by exploring its fathomless growth potentialities. 


\section{Strategic \& Climatic Advan Tage}

All-weather port.

Tropical and dry climatic conditions to handle any type of cargo throughout the year

Temperature varying from 25 degree Celsius to 44 degree Celsius.

$>$ Scanty rainfall facilitates round-the-year operations.

$>$ Uninterrupted and smooth port operations on 365 days a year.

$>$ No adverse wave effect, being a protected and sheltered harbour situated in the Creek.

$>$ The only Indian Major Port nearest to the Middle East and Europe.

\section{The Port Logistics}

\subsection{Navigational Facilities}

$>$ Round-the-clock navigation

$>$ Permissible draught 12.6 mtrs.

$>$ Ships with 240 mtrs. length overall and 65,000 DWT are accommodated presently.

$>$ Safe, protected and vast anchorage at outer harbour for waiting and lighterage purpose.

$>22$ lighted navigational buoys with solar lights, as per IALA system, are provided in the navigational channel.

$>$ Light house as an aid for night navigation.

$>$ Fully equipped signal station operational round-the-clock. Four lighted shore beacons.

\subsection{Research Methodology}

The Present research is an analytical study of Development of Ports in Saurashtra and Kutch region. The various aspects of performance of various ports are analyzed with the help of the information contained in the research papers, reports, journals, websites, reference books, newspapers and magazines. Secondary data are used in this study. Income statement, Balance sheets, Annual reports of concerned companies, Concerned books, Magazines are referred for collection of secondary data. Data provided in the internet have also been used.

\subsection{Significance of Study}

The study done on the above topic will give an idea of how the ports are developed and what are the problems are faced when developing a new port. The project will be help full in finding out what strategies to make in order to fulfill the needs of the port environment and requirements have been analysed to construct the ports in the Saurashtra and Kutch region.

\subsection{Research Hypothesis}

If growth of port is related to foreign trade volume then more increases in the port growth the bigger will be the foreign trade volume.

\subsection{Review of Literature}

1. The article written by Swaminathan \& Anklesaria Aiyar appeared in the Business Standard on Dec. 112008 which based on benefits of port liberalization: highlights the efficiency of port industry of Gujarat which also developed new industries like ship building. Gujarat has implemented various forms of port liberalization since 1990 's. This has helped it become the country's fastest growing state.

2. According to ADB (2000) report based on private sector participation mentioned following objectives.

(i) Provide services which are efficient and cost effective from the port user's perspetive.

(ii) Respond to changes in cargo handling technologies.

(iii) Respond to the changing requirements of the port users.

(iv) Provide choice of services and faster competition.

(v) Make timely capital investment to improve efficiency and expand capacity 
(vi) Generate funds needed to finance investments.

(vii) Enforce labour discipline in the face of strong trade unions.

3. Roach D.K. (1982) Improving port performance: Management of general cargo operation,Trainee's workbook, Cardiff, U.K.: Droke educational associates U.K. Book. Roach mentioned in his studies about to reduce the cost of transport cost. According to him - Ship turn around time is an excellent indicator the speed of services being provided to ship operators. It is very important element in maritime transport costs.\|

4. According to the study of ASSOCHAM in year 2010 on 30 new ports may come up along Gujarat coast: Explained about scope for development of about 30 new ports along the $1600 \mathrm{Km}$ Gujarat coast. Therefore, Gujarat would see an investment of nearly Rs. 90,000 crore in the coming five years. The study also pointed out increase in employment opportunities.

5. The thesis written by Michele Acciaro in 2003-04 at Erasmus university, Rotterdam on private sector financing of container terminal infrastructure: proposes and evaluates some obstacles in this and explains why they prevent private financing of container terminal infrastructure. It also indicates possible solutions to overcome these obstacles finally it assess the level of private financing of container terminals achievable in Europe.

6. Article published by Kevin Cullinane, Mahim Khann in journal of transport geography in year 1999 : given about to increase sufficient infrastructure facilities like berths, depth of water and craneage which fewer ports will be in position to compete for these larger and larger ships.

7. According to (World Bank, 2001) - private sectors involvement in the port should not be an end in itself, but only a mean to achieve specific and well-defined public interest objectivesll.

8. These objectives obviously vary from port to port and from context to context, but in general larger private involvement in the

\section{PORT SECTOR IS MOTIVATED BY}

$>$ The need to increase competitiveness in the port;

$>$ The desire to stimulate the port based regional economy;

$>$ The need to reduce public budget expenditure.

To focus on the integrated development of the sector for its sustained growth, Gujarat Maritime Board, along with confederation of Indian industries has organized a conference on -Port led development in Gujarat\| on $29^{\text {th }}$ June 2010: The theme was in tune with the current scenario focusing on the holistic and inclusive development near ports and along the coast, to sustain long term development of ports and port led activities.

Further in the creation and sustenance of these support activities, these centers have to be socially livable and acceptable for the overall socio- economic development of the region.

The special focus was given to the logistic policy formulation, integrated logistics solutions, skill development, and capacity enhancement of the existing ports, coastal shipping building of support infrastructure and other activities in support of strong and road connectivity.

\section{LIMITATIONS OF RESEARCH}

There is limited literature available in market about the subject. The procedure to visit the place and collect the data complex.

In this study, only sample data from different sources are taken due to time and cost constraints. 
Online references sometimes mismatch with one another therefore accuracy of reports presented in thesis is limited.

Complete accuracy not possible due to errors in feedback.

Few persons have conduct the research in the region on the port therefore It was difficult to gate information about the same.

Feedbacks might not be entirely truthful which depends on secondary source.

\section{REFERENCES}

[1] Abeyratne, S. (1997) Trade Strategy and Industrialization in W.D. Laxman ed. Dilemmas of Development Fifty years of Economic Change in Sri Lanka 341- 385.

[2] Aggarwal (2004 a) Export Processing Zones in India: Analysis of the Export Performance, ICRIER, working paper No. 148.

[3] Aggarwal (2004 b) 'The Influence of Labour Markets on FDI : Some Empirical Explorations in Export Oriented and Domestic Market Seeking FDI Across Indian States, Unpublished manuscript.

[4] Aggarwal, A. (2002) Liberalisation, Multinational Enterprises and Export Performance : Evidence from Indian Manufacturing (2002), Journal of Development Studies, Vol 38, No. 2, 119-137.

[5] Andersson T. and T. Freriksson (1995) 'International Organisation of Production and Variation in Exports from Affiliates, Journal of International Business Studies 27(2), 249- 263.

[6] Armas E.B. and M. Sadni Jallab (2002) A Review of the Role and Impact of Export Processing Zones in World Trade: The Case of Mexico, Working paper 02-07 Centre National de la Recherche Scientifique

[7] Athukorala, P. (1997) Foreign Direct Investment and Manufacturing for Exports in W.D. Laxman ed. Dilemmas of Development Fifty years of Economic Change in Sri Lanka 386-422.

[8] Baissac Claude (2003) Maximising the Developmental Impact of EPZs: A Comparative Perspective in the African Context of Needed Accelerated Growth A Presentation at the Johannesburg EPZ Symposium October 15-16, 2003.

[9] Cling, J.P. and G. Letilly (2001) "Export Processing Zones: A threatened instrument for global economy insertion?" DT/2001/17 Paris: DIAL

[10] Dunning [1998] 'Changing Geography of Foreign Direct Investment: Explanations and Implications in Nagesh Kumar et al. Globalisation, Foreign Direct Investment and Technology transfers: Impacts on and Prospects for Developing Countries, London and New York: Routledge.

[11] Dunning, J.H. (1980). Toward an Eclectic Theory of International Production: Some Empirical Tests, Journal of International Business Studies. 11(1): 9-31.

[12] Dunning, J.H. (1993) Multinational Enterprises and the Global Economy, Reading: Addison- Wesley

[13] Dunning, J.H. and Buckley,P. (1977) International production and Alternative Models of Trade. The Menchester School of Economics and Social Sciences XLV, Dec. 392-403.

[14] EXIM (2000) Export processing Zones in select countries: Critical Success factors' Occasional paper 74, Export Import Bank of India, 2000

[15] Ferrerosa T, J.H. (2003) 'Free Zones as Logistic Platforms and Their Impact in the Development of Latin American Countries', www.iajbs.org.

[16] Goswami et al (2002) 'Competitiveness of Indian Manufacturing: Results from a Firm Level Survey' A World Bank-CII study.

[17] Hinkle, L.E., A. Herrou-Aragon and K. Kubota (2003), "How Far Did Africa's First Generation Trade Reforms Go? An Intermediate Methodology for Comparative Analysis of Trade Policies", Africa Region Working Paper No 58, World Bank, Washington D.C.

[18] ICIR (1992) Review of Overseas Export Enhancement Measures, The Industry Commission Inquiry Report, 1992 , Australian government, productivity Commission.

[19] ILO/UNCTC (1988) Economic and Social Effects of Multinational Enterprises in Export Processing Zones, Geneva, Switzerland.

[20] JOHANSSON H. [1994], 'The economics of export processing zones revisited', Development Policy Review, Vol.12, pp.387-402.

[21] Kankesu J. (2003) Benefit-Cost Appraisals of Export Processing Zones: A Survey of the Literature, Development Policy Review 21(1).

[22] Keddie, J. (1976) ‘Adoption of Production Technique in Indonesia Industry’, Ph.D.Dissertation, Harvard University 
[23] Kumar , N. (2003) Host Country Policies, WTO Regime and the Quality of Foreign Direct Investment : A Quantitative Analysis of the Role of Multinational Enterprises in industrialisation, Export orientation and Innovation in Host Countries, Oxford University Press.

[24] Kumar Rajiv (1989) 'Indian Export processing Zones: An Evaluation’ Oxford University press, New Delhi, 1986.

[25] Kundra A. (2000) : 'The Performance of India's Export Zones : A Comparison with the Chinese Approach,' Sage Publication., New Delhi

[26] Loree, W.D. and S.E. Guisinger 1995 Policy and Non Policy Determinants of US Equity Foreign Direct Investment, Journal of International Business studies, 26(2), 282- 299.

[27] Madani, D. (1999) A Review of the Role and Impact of Export Processing Zones. Washington, DC: World Bank.

[28] Mattoo, Aaditya, Devesh Roy and Arvind Subramanian (2003), "The African Growth and Opportunity Act and its Rules of Origin: Generosity Undermined?" The World Economy, Vol. 26, Issue 6, June, pp.829-851.

[29] Mitra, A. et. al (1998) ' State Infrastructure and Productive Performance in Indian Manufacturing, Technical paper 139, OECD Development Centre.

[30] Mody A. and K. Srinivasan (1996) ' Japanese and United States Firms as a Foreign Investors : Do they march to the same tune? World Bank Mimeo, W.B. Washington.

[31] Mondal A.H. (2001) Role of the Export Processing Zones in the Industrialization Process of Bangladesh: Lessons for the Future" (published as Chapter 6, in Rushidan Islam Rahman (ed.), Performance of the Bangladesh Economy: Selected Issues, Bangladesh Institute of Development Studies, Dhaka, 2003, pp. 93 - 122.

[32] Mondal, A.H. (2003) Role of the Export Processing Zones in the Industrialization Process of Bangladesh: Lessons for the Future" in Rushidan Islam Rahman (ed.), Performance of the Bangladesh Economy: Selected Issues, Bangladesh Institute of Development Studies, Dhaka, 2003, pp. 93 - 122.

[33] Nankani, G. (1979). "Development Problems of Mineral-Exporting Countries”, World Bank, Staff Working Paper, no. 354, Washington.

[34] OTA, Tatsuyuki ( 2003) ' The Role of Special Economic Zones in China's Economic Development as Compared with Asian Export Processing Zones : 1979-1995' Asia in Extenso, March 2003.

[35] Papanastassiou, M. and Pearce, R. D. 1990. Host country characteristics and the sourcing behavior of UK manufacturing industry. Working Paper. University of Reading, Department of Economics. Discussion Papers in International Investment and Business Studies, Series B, 2. No. 140.

[36] Porter, M. E. (1990) : 'Competitive Advantages of the Nations' Reuber G.L. et. al (1973) Private Foreign Investment in Development Oxford, Claredon Press.

[37] Ryan, P.F., A.N.Savage and M.G.Willis (1993) Infrastructure of Private EPZs -Role of the state and the Private Zone operator in R.L.Bolin (ed) Public Vs Private Free Zones. Flagstaff Institute.

[38] Subramaniam, A. and D.Roy (2001) Who Can Explain The Mauritian Miracle: Meade, Romer Sachs or Rodrik? Working Paper No.01/116, The World Bank.

[39] TCS (1976) 'Techno-Economic Potential Survey of Tamil Nadu’ Draft Reports Vol. III Case Studies (mimeo) Bombay. 1976.

[40] Tekere M. (2000) Export Development and Export led growth Strategies: Export Processing zones and the Strengthening of Sustainable Human Development, ICTSD Globalisation Dialogues- Africa Windhoek, 10-12 may 2000, 37-55.

[41] Tondon Committee (1982) 'The Committee on Free trade Zones and 100\% Export oriented Units, Appointed by the Ministry of Commerce, Government of India, September 1981.

[42] UNCTAD (1998) World Investment Report 1998, United Nations, New York.

[43] UNCTAD( 1999) World Investment Report 1999 UNCTAD.

[44] UNIDO (1995) Export processing Zones : Principles and Practices Vienna : UNIDO 1995.

[45] Watson P. (2001) Export Processing Zones : has Africa Missed the Boat? Not yet! Africa Region Working Paper Series Number 17, 2001.

[46] Watson P.L. (2001) 'Export Porcesing zones : Has Africa Mised the Boat? Not yet! Africa Region Working paper Series Number 17. 